\title{
Effect of Macroeconomic Variables on Agricultural Development in Nigeria (1981-2016)
}

\author{
Akinniran*, Taiwo Nuraeni and Osadare, Bukunmi Sarah \\ Department of Agricultural Economics, Ladoke Akintola University of Technology, P. M. B. 4000, Ogbomoso, Nigeria
}

\author{
*Corresponding Author \\ Akinniran

\section{Article History} \\ Received: 10.08 .2020 \\ Accepted: 18.08 .2020 \\ Published: 23.08.2020
}

\begin{abstract}
This study examines the effect of macroeconomics variables on agricultural development in Nigeria between 1981-2016. To achieve the research objective Secondary data obtained from the Central Bank Statistical bulletin, and Food and Agricultural Organization were used for the study. Augmented Dickey Fuller unit root test and cointegration test were employed to analyse the data collected. The ADF test conducted on the variables showed that while government expenditure on agriculture was stationary at level, agricultural GDP, credit to agricultural sector, external debt, crude oil price, exchange rate, and interest rate were however stationary at first difference. The Engel Granger test makes fewer distribution assumptions and does not allow the identification of the number of co-integration vectors. The result of the error correlation model showed that in the long run, CAS (Credit to the Agricultural Sector) and Ex. Rate (Exchange Rate) exerted significant positive influence on agricultural development while Ex. Debt (External Debt), COP (Crude Oil Price), Gov. Exp (Government Expenditure on Agriculture) and IR (Interest Rate) failed to significantly explain the variation in agricultural development in Nigeria during the period under investigation. This can be due to inappropriate priority settings to profligate living instead of food production through to the masses by the government, implying that the government has been indulging in deficit financing over the years resulting in an increase in the rate of inflation. This again will lead to an increase in input prices, thereby affecting the output of the agricultural sector. It is therefore concluded that Credit to the Agricultural Sector (i.e. proper funding) and Exchange Rate are indispensable for sustained agricultural development in Nigeria.
\end{abstract}

Keywords: Government expenditure, Interest rate, External debt, Exchange rate, Oil price.

\section{INTRODUCTION}

Agriculture as a branch of the world economy plays a significant role in human life. Its main goal is to meet the population's needs for food and provide the industry with raw materials. In the pre-Independence era, the agricultural sector contributed most to the GDP of Nigeria. Between 1964 - 1965, agriculture accounted for 55\% of GDP and employed $70 \%$ of the adult workforce [1]. In 1970, agricultural export crops like cocoa, groundnut, cotton, rubber, palm oil, palm kernel, etc. However, due to discovery of oil in early 1970s agricultural sector was neglected and the country moved from a position of self-sufficient in food and cash crop production to highly reliance and dependent on importation of food to feed her increasing population Akinniran [2].

Agriculture has been defined as the production of food and livestock, and the purposeful tendering of plants and animals [3]. He stated further that agriculture is the mainstay of many economies and it is fundamental to the socioeconomic development of a nation because it is a major element and factor in national development. In the same view, Okolo [4] described agricultural sector as the most important sector of the Nigerian economy which holds a lot of potentials for the future economic development of the nation as it had done in the past. Notwithstanding the enviable position of the oil sector in the Nigerian economy over the past five decades, the agricultural sector is arguably the most important sector of the economy. Agriculture's contribution to the GDP has remained stable at between 30 and 42 per cent, and employs 65 per cent, of the labour force in Nigeria [5].

Copyright @ 2020: This is an open-access article distributed under the terms of the Creative Commons Attribution license which permits unrestricted use, distribution, and reproduction in any medium for non commercial use (NonCommercial, or CC-BY-NC) provided the original author and source are credited. 
Literature has provided evidences on the relationship between agricultural development and macroeconomic variables in Nigeria. Agricultural development is a complex process which requires changes in agricultural productions patterns, chemical and mechanical innovation as well as creation of the adoption of such innovations by all and sundry [6]. Agricultural development can also be seen as a tool for determining the extent of development in a country. According to the theory of economic development propounded in 1954 by Lewis, agriculture was regarded as the source for industrial growth and development. Agriculture is the engine of growth and development of most nations; it has frequently been regarded essential in the advancement of the economy, as well as one of the major approaches to controlling poverty in most underdeveloped nations. Statistics have proven that agriculture is the most important Nigerian economic sector in terms of its contribution to the GDP, after oil. The sector contributes about $41 \%$ of the country's GDP, employs about $65 \%$ of the total population and provides employment to about $80 \%$ of the rural population [7]. The development and growth of most developing nations arises from the functions of agriculture alongside its relationships with other sectors of the economy. In view of this, it is presumed that agriculture is one of the foremost determinants in achieving economic development, whether the battle over poverty and the achievement of longterm economic development will be won or lost Eyo [8]; Omotor, et al, [9]. Despite the decline in the share of agriculture in GDP, it continues to play a significant role in the development of the economy and society, provides a large number of jobs, produces food, raw materials, and contributes to food security, poverty reduction; it also contributes to the development of trade and the economy.

Agricultural development is one of the most powerful tools to end extreme poverty, boost shared prosperity and feed a projected 9.7 billion people in 2050 (worldbank.org). Growth in the agriculture sector is two to four times more effective in raising incomes among the poorest compared to other sectors. 2016 analyses found that $65 \%$ of poor working adults made a living through agriculture (worldbank.org). Agriculture is also crucial to economic growth such that in 2014, it accounted for one-third of global gross-domestic product (GDP).

On the other hand, macroeconomics refers to the study of a nation's overall economic performance. The federal government tries to influence the performance of the national economy through various policies such as changing the level of taxation, government spending, or the supply of money available in the economy. Changing macroeconomic policies affect national income, prices, interest rates and exchange rates all of which influence the agricultural economy. Macroeconomic variables are dynamic elements in the economy system that affects all sectors' activities. Macroeconomics studies the behaviour of economic aggregates. Macroeconomic variables are associated with economic aggregates: a country, a region, the population of a country, all companies in a country etc. There are 4 main macroeconomic variables that policymakers should try and manage: Balance of payments, inflation, economic growth and unemployment. Macroeconomic variables are indicators or main signposts signalling the current trends in the economy. Like all experts, the government, in order to do a good job of macro-managing the economy, must study, analyse and understand the major variables that determine the current behaviour of the macro-economy. The macroeconomic variables that past researchers normally selected are gross domestic product(GDP), total trade (XM), foreign direct investment (FDI) < inflation rate (INF) and interest rate (INT) Hence, understanding the relationship between the agricultural development and macroeconomic variables in the economy will fine-tune the path for sound policies on economic growth in the country.

In Nigeria, the improvement of agriculture has been a little below moderate despite the different methods of approaches that has been put to practise. In fact, a number of programs have been presented by the government to enhance the circumstance ever since the 1970s. These programs included encouraging mechanised large scale farming by both the federal government and state government. National Acceleration of Food Production (NAFP), River Basin Development Authority (RBDA), Operation Feed the Nation (OFN), Structural Adjustment Program (SAP), and recently N-POWER and so on are part of the programmes introduced. However, SAP was implemented to serve as an economic liberalization for the country. Likewise, the government established the Agricultural Credit Scheme (ACS) to resolve the financial aspect Omotor et al. [9].

Nigeria faced several economic crises which can be characterised with mass unemployment, persistent inflation rate, immense economic debt, balance of payments disequilibrium, and extreme shortage of fundamental raw materials; before the economy deregulation by the introduction of SAP in July 1986. The SAP embraced in Nigeria in the late 1980s, is an approach aimed at boosting agricultural sector. The introduction of SAP was to remedy the situation by restructuring and diversifying the prolific state of the economy.

In spite of all these measures, the slow growth of agricultural sector has created issues like insufficient food for the populace, inadequate raw materials for industries, and decrease in the rate of foreign exchange earnings. However, the growth rate of agricultural production over the years has been either stagnated or neglected to keep pace with the country's fast growing populace. This resulted into shortage of food, continuous inflating food prices and mass food importation by the government. 
In line to these mentioned facts, will result to the question; what are the effects of macroeconomic variables on agricultural development in Nigeria? The economic and physical welfare of the country can depend on increasing and stabilising of agricultural output through more effective policies, technologies, programmes and practices, also it should be noted that agricultural roles cannot be overstressed in transforming the economic framework of any country, given that it serves as source of food for man and animal, provision of raw materials and likewise helps in poverty reduction of most countries. To this end, this article is designed to examine the effects of macroeconomic variables on agricultural development in Nigeria, determine the effect of agricultural development on the economic growth of Nigeria, discuss the impacts of macroeconomic variable on agricultural production, examine if agricultural development will yield the quantity of output and to assess the trends in agricultural development with respect to production. Also, null hypothesis "there is no significant relationship between the effects of macroeconomic variables on agricultural development" was tested.

This study is motivated by the crucial significance of agricultural production and development in the Nigerian economy. Nigeria is an agrarian country, in the structure of the economy, agriculture accounts for 39\% of GDP, with the overwhelming majority of the economically active population occupying it (Legit.ng). Agriculture has been in deep decline over the past few decades, having lost its ability to adequately provide the population with food and other products, as well as to produce commodity products, the export of which would give the country significant foreign exchange earnings [10]. Several factors affect or enhance agricultural production and development in the agricultural sector. These factors include drought and crop failure, global warming, climate change, water pollution, rising migration from rural to urban areas, as well as rising incomes. Others are taxation, inflation, employment, value of agricultural import, government policies and infrastructural facilities etc. Empirical studies on the quantitative analysis of the determinant of the scale of agricultural production and development are few. These few studies focused on factors such as those mentioned above without considering the impact of crude oil price, credit to agricultural sector, interest rates and other allied factors. This study identified various macroeconomic variables influencing the development of agricultural production in Nigeria, with emphasis on agricultural GDP.

This study was designed to serve as a useful tool and material to students, researchers, extension agents, and other individuals from the cooperate world who may find the work a worthy guide helpful for other research works, to validate specifically the effect of macroeconomic variables on agricultural production and development and form the basis upon which planning decisions and suggestions will be made as to how various macroeconomic variables affect agricultural production.

\section{CONCEPTUAL FrameWORK Variables}

Variables can be defined as any aspect of a theory that can vary or change as part of the interaction within the theory. In other words, variables are anything that can affect or change the results of a study. Every study has variables, as these are needed in order to understand differences. A variable is any item, factor, or condition that can be controlled or changed (Study.com).

\section{Macroeconomic Variables}

Macroeconomics variable is the study of the economy as a whole, and the variables that control the macroeconomy. It is the study of government policy meant to control and stabilizes the economy over time, that is, to reduce fluctuations in the economy. It can also be referred to as the study of monetary policy, fiscal policy, and supply-side economics. The major variables describing the macro-economy and policy approaches for all countries are the same, but the quality to which these policies are applied differ from one country to another; this is because the political process from which policies emerge are unique to each country (Wikipedia) [26]. Macroeconomic variables are indicators or main signposts signalling the current trends in the economy (business dictionary). Like all experts, the government, in other to do a good job of macro-managing the economy, must study, analyse, and understand the major variables that determine the current behaviour of the macro-economy. So government must understand the forces of economic growth, why and when recession occur, and anticipate these trends, as well as what mixture of policy will be most suitable for curing whatever ills the economy had. How the economy moves over time depends on its structure, institutions, and policies all of which are subject to large historical changes. It would be surprising if the character of the business cycle did not change in response to such far-reaching developments as the great contraction of the 1930s and post-depression reforms, the expansion of government and private service industries, the development of fiscal and other built-in stabilizers, and the increased use ad role of discretionary macroeconomic policies Zarnowitz [11].

\section{Agricultural Production}

Agriculture is the process of producing food, feed, fibre and many other desired products by the cultivation of certain plants and the raising of domesticated animals (livestock). Modern agriculture extends well beyond the traditional production of food for humans and animal feeds. Other agricultural production goods include timber, fertilizers, animal 
hides, leather, industrial chemicals (starch, sugar, alcohols and resins), fibres (cotton, wool, hemp, silk and flax), fuels (methane from biomass, ethanol, biodiesel), cut flowers, ornamental and nursery plants, tropical fish and birds for pet trade, etc (sciencedaily.com). Also, agricultural production accounts for less than five per cent of the gross world product (an aggregate of all gross domestic products) (Wikipedia). Generally, the agricultural sector contributes to the development of an economy.

\section{Agricultural Development}

Agricultural development is the ability to develop some "better" system of agricultural production (sciencedirect.com).. For many rural poor the world over, human labour is a major constraint to greater agricultural production. Labour constraints during the ploughing, weeding, or harvesting seasons are where oxen can most easily fill the gap between what people can do and what they would like to do. Greater efficiency and timeliness are easily accomplished if oxen are employed in all agricultural operations. Many farmers plough with oxen and then leave them idle for the remainder of the year. Employing the animals in labour-saving and profitable ways year round takes a great deal of creativity. However, this creativity can pay great dividends when greater harvests are possible. The implements needed for ploughing, weeding, and transportation are often a larger constraint for many farmers than the acquisition, training, and employment of animals.

Agricultural development brings about a revolution in the agricultural industry, to give birth to an agriculture which is profit giving and at the same time eco-friendly. Agricultural development means providing assistance to the crop producers with the help of various agricultural resources. Providing protection, assisting in the research sphere, employing latest techniques, controlling pests and facilitating diversity, all fall within the purview of agricultural development.

Attaining a stable and sustainable development is a major goal of most nations round the globe, which brought about different economic schools of thought ranging from the classical to the neo views. The neo- classical exogenous development theory has commonly been the significant school of thought in the discussion of development theory over decades. The Solow -Swan neo-classical growth model explains that in long-run, the growth rate of output is based on two exogenous variables. The theory concludes that output growth is determined by technical progress and growth in capital and labour inputs. This model provides few channels for macro-policy influences. Thus, technical progress is assumed to be exogenous and most empirical studies do not suggest that macro-policies have much influence on labour force growth.

Macroeconomic policies serve as instruments through which government of an economy tries to regulate economic affairs of a country in line with their set objectives. This can either be through monetary or fiscal policies. Monetary policy involves government control of the money supply in an economy using certain instruments. In other words, monetary policy is a deliberate attempt to control money supply and credit condition through manipulation of interest rate for achieving certain broad economic objectives like economic growth, stability in the rate of inflation and exchange rate as well as employment; Rightsman [12]. Monetary policy can either be expansionary or contractionary. It is contractionary if it is aimed at reducing the size of money supply or raising the interest rate, while for an expansionary policy the reverse is the case. Fiscal policy on the other hand involves the use of government expenditure, taxes and subsidies inform of reliefs to promote growth. These instruments can be grouped in to two, i.e. automatic stabilizers and discretionary fiscal policy. Automatic stabilizers relate to government spending or cut in tax which does not involve deliberate government actions but helpful in regulation fluctuations in economy, while discretionary fiscal policy involves deliberate actions taken by the government in order to achieve certain macroeconomic objectives; Rights man [12]. As a whole, the macroeconomic policies consists of the fiscal, monetary, exchange rate regimes and trade policies, that determine production outcomes in the real sectors and other sectors including the agricultural sector. Regrettably, macroeconomic policy outcomes in any economy differ depending in part on the policy instruments employed, policy objectives as well as operating environment. Fischer's theory as cited by Lachaal [13] listed five conditions, which together imply that a macroeconomic framework is conducive to growth. These are; a low and predictable inflation rate; an appropriate real interest rate; a stable and sustainable fiscal policy; a competitive and predictable real exchange rate and a balance of payment that is regarded as viable. Therefore, in examining the relationship between macroeconomic variables and agricultural production, this research presented models based on the existing literatures where a production function framework, in which labour, capital, export terms of trade and other factors are used as the explanatory inputs.

Using econometric approach to estimate the total factor of productivity for the United States dairy industry between 1972-1992, Hameed [13] examines how protectionist policies in the form of direct subsidies to agriculture reduced productivity growth in the United States dairy industry. He found that government subsidies encouraged using materials at the expense of feed and raised the cost of production by $1.8 \%$ for each $10 \%$ increase in subsidy. In a related study on the impact of trade restrictions on agricultural productivity, Fan et al. [14] found that import restrictions result into inefficient use of limited resources. They further stated that oil export in Nigeria has led to increased inflow of 
foreign currency. This does not only have depreciating effects on the value of Naira but also reduced the competitiveness of the country's domestic produced agricultural goods in comparison with low-priced imported goods, leading to a reduction in agricultural output, thereby, exposing people to food insecurity and leading to poor economic growth.

In Nigeria, a study by Yaqub [15] on the sectoral analysis of the impact of exchange rate on output in Nigeria, using apparently unrelated regression estimation technique found that exchange rate had a significant contractionary effect on Agricultural output, hence existing structures do not support an expansionary depreciation argument. In a related study by Adetoun [16], using the descriptive statistical analysis, his result reveals that change in monetary policy instruments cause changes in agricultural output with a long-run equilibrium relationship between the monetary policy variables and growth in output. The study further recommended that enlightening the farmers on how monetary policy changes affect agricultural output is the first step in making farmers and agro-businesses become active players in the policy making process. Looking at the impact of agricultural finance on output in Nigeria, using a cross sectional data, Egbuwalo [17] observes that agricultural finance remained a thing of interest in the effort to raise agricultural output. The above is in line with Enoma [18] who examines the impact of agricultural credit on the growth of GDP in Nigeria. In his study, measures aimed at increasing agricultural production were discussed and the relationship between agricultural development and economic growth were highlighted. The author concludes that agricultural credit, interest rate and exchange rates were all important in affecting aggregate output in Nigeria. In the same measure, Sunday et al. [19] investigating the short-run and long-run elasticity of agricultural productivity with respect to some key macro-economic variables, using the techniques of co-integration and error correction models. Their result revealed that in the short and long-run periods, the coefficients of real total exports, external reserves, inflation rate and external debt have significant negative relationship with agricultural productivity in the country, whereas industry's capacity utilization rate and nominal exchange rate have positive association with agricultural productivity in both periods.

A handful of other researchers have also attempted to investigate the relationship between agricultural growth and macroeconomic policy through the test of causality, although with mixed results. Looking at the causality between exports and Agricultural output in Pakistan using ARDL, Memon et al. [20] found bi-directional Granger-causality relationship between total exports and agricultural GDP while Salih [21], present empirical evidence showing a significant long run relationship between agricultural output growth and economic growth (income) that assumes bidirectional causation. In the case of Nigeria, his investigation shows the relationship between value of agricultural GDP as the ratio of total GDP and some key macroeconomic variables. Estimating the chain of causality using F-statistic for both short and long run period the test result reveal that there exists a unidirectional relationship running from macroeconomic variables to agricultural productivity. He concludes, total variation in agricultural productivity are induced by changes in macroeconomic variables. From the above, one can conclude that the development of agricultural production is largely hinge on the stability of some key macroeconomic fundamentals.

Poverty is one of the major problems facing Agricultural development in Nigeria. Insufficient funds or capital can limit farmers from acquiring large hectares of land in order to practice mechanised farming. This can lead to reduction in the production of foods.

\section{Methodology}

This study was carried out in Nigeria, one of the most populous countries in the sub-Sahara African countries situated on the Gulf of Guinea in the Western African region between the latitudes of 3" $10 \mathrm{~N}$ to 14 " $45 \mathrm{~N}$ and between longitudes 3"'42E. It is bounded in the North by the Niger Republic and Chad, in the West by Benin republic, in the East by Cameroon Republic and the South the Atlantic Ocean. Nigeria is divided into six geo-political zones; North-East, North-West, North-Central, South-East, South-West, and South-South. Nigeria has thirty-six (36) States and a Federal Capital Territory (Abuja), and consists of 774 Local Government Areas.

The current population of the study is 201,803,703 as of Friday, August 30, 2019, based on the latest United Nations estimates. Nigeria population is equivalent to $2.61 \%$ of the total world population. Nigeria ranks number seven (7) in the list of countries (and dependencies) by population. The population density in Nigeria is 221 per kilometre square (571 people per mi-square). The total land area is $923,768 \mathrm{~km}$-square $(356,669 \mathrm{sq} \mathrm{mi})$, making it the world's $32 \mathrm{nd}-$ largest country (Nigeria-Wikipedia); $51.2 \%$ of the population is urban (102,805,995 people in 2019), and the median age in Nigeria is 17.9 years.

Nigeria is an agrarian country; as a result, agriculture is a major employer of labour providing employment for about $30 \%$ of the total population [24]. The boon of the agricultural sector to Nigeria economy include the contribution to the gross domestic product (GDP), employment opportunities, increases foreign exchange, provision of food, and provision of raw materials for agro-allied industries. The country is largely endowed with abundant natural resources and favourable tropical climate which allows the production of livestock, crops, fisheries, forestry and wildlife. Time series data at the macro level covering between the periods of 1980-2016 were used for the purpose of this study. The data were 
largely sourced from the Central Bank of Nigeria (CBN) [22] statistical bulletin, and an online database maintained by Food and Agricultural Organization (FAO) statistical data base for United Nations. The data collected were analysed through the use of the unit root and co-integration test.

Unit Root Test; if a time series have a unit root, it shows a systematic pattern that is unpredictable. A unit root attempts to determine whether a given time series is consistent with the process, i.e. it is used to test for stationarity (a stochastic process whose joint probability distribution does not change when shifted in time i.e.to determine whether the statistical properties such as mean, variance etc. are constant and do not change over time) or non-stationarity under time series variables. Previous studies indicated that time series data for Agricultural GDP (Ag. GDP), External Debt (Ex. Debt), Crude Oil Price (COP), Exchange Rate (Ex. Rate), Government Expenditure on Agriculture (Gov. Exp), Interest Rate (IR), are likely to be non-stationary and according to Engel-Granger [23] using data series that are not stationary for statistical analysis often result in spurious regression (i.e. a mathematical relationship in which two or more variables are not causally related to each other, yet it may be wrongly inferred that they are, due to either coincidence or the presence of a certain third unseen factor called a confounding factor or a lurking variable not apparent at the time of examination. It is a false presumption that two variables are correlated when in reality, they are not). Hence, to overcome this, the data would be examined for stationarity (i.e. test for stability) using the test developed by Augmented Dickey Fuller (ADF) Dickey Fuller in 1979, which is used to test for a unit root in a time series sample or autoregressive model.

Co-integration Test; Co-integration is said to exist between non-stationary variables if their linear combination, namely the residual of co -integration regression is stationary [23] i.e. it establishes the stationarity of the residuals generated from running a static regression at a level of the independent variable on the dependent variables. This test will help to identify whether there is causality between the variables under consideration. This study employs the cointegration and Error Correction Model in analysing the data, and the test is carried out to determine the long-run relationship between the independent variable when one or more of the variable are non-stationary at a level which means they have a stochastic trend [25] or to check if the independent variable(s) can predict both at present (short-run) or future long-run.

\section{Model SPECIFICATION}

The model for this research is specified thus:

$\mathrm{Y}=\mathrm{f}\left(\mathrm{X}_{1}, \mathrm{X}_{2}, \mathrm{X}_{3}, \mathrm{X}_{4}, \mathrm{X}_{5}, \mathrm{X}_{6}, \mu\right)$

Where: $Y=$ Agricultural GDP, $X_{1}=\mid$ External Debt, $X_{2}=$ Crude Oil Price. $X_{3}=$ Exchange Rate, $X_{4}=$ Government Expenditure in Agriculture, $X_{5}=$ Credit to Agricultural Sector, $X_{6}=$ Interest Rate and $\mu=$ Error Term The following production functions were explicitly fitted to the model:

$Y=\beta_{0}+\beta_{1} X_{1}+\beta_{2} X_{2}+\beta_{3} X_{3}+\beta_{4} X_{4}+\beta_{5} X_{5}+\beta_{6} X_{6}+\mu$

The presence of the error term $(\mu)$ took care of other variables that were not stated in the model specified but have an influence on agricultural GDP.

\section{RESULT AND DisCUSSIONS}

Credit to agricultural sector in Nigeria between the year 1981-2016.

Credit in agriculture is to acquire any kind of productive assets, land and/or machinery. Credit provides the means for many farmers to adjust their operations to keep up with the constant changes related to agriculture, and by doing so, to improve their operations. Therefore, an increase in credit to agricultural sector, will lead to an increase in agricultural production in Nigeria. The result in Figure 1 shows the time trend of credit to agricultural sector in Nigeria in US dollars. The graph reveals that between 1980-1990, there was no flow of credit to the agricultural sector, it shows a regular flow from year 1991-2010, and it gradually increased in form of slopes and steeps from the year 2010, up to the year 2016.

\section{Agricultural GDP in Nigeria between the years 1981-2016}

Agricultural GDP is the Gross Domestic Product (GDP) coming from the agricultural sector. The GDP is the monetary value of all the finished goods and services produced within a country in a specific time period. The graph (fig. 2) shows the trend of agricultural GDP over the years. It shows that the GDP was very low around 1980-1990, and it began to increase slightly with a slope between the years 1990-2000. The trend however continued to increase steeply up to the year 2016 .

\section{Crude oil price in Nigeria between the years 1981-2016}

Crude oil price influences the prices of agricultural products that its sudden changes affect the stability of prices mainly food prices which are derived from agricultural produce. The graph below (Fig 3) shows the movement of crude 
oil price ranging from 1981-2016, year 1987 has the lowest COP, and year 2009 has the highest COP while it continues to rise and fall over the years.

\section{Exchange rate in Nigeria between 1980-2017}

An exchange rate is the value of one nation's currency versus the currency of another nation or economic zone. For example how many U. S. dollars does it take to buy one Naira? Sometimes country will peg its currency to that of another nation. It is the rate at which one currency will be exchanged for another; it is also regarded as one country's currency in relation to another currency. Exchange rate graph (fig 4) shows a regular simultaneous flow and increase in Exchange. Rate from year 1981- 2009, it further continued to increase from 2009 over the years.

\section{Nigeria external debt between 1981-2016}

External debt is the portion of a country's debt that is borrowed from foreign lenders through commercial banks, governments or international financial institutions. If a country cannot repay its external debt, it faces a debt crisis. If a nation fails to repay its external debt, it is said to be in sovereign default (www.investopedia.com). It is the total debt a country owes to foreign creditors. These loans, including interest, must be paid in the currency in which the loan was made. External debt graph (Fig 5) revealed that year 1981-1987 was relatively low, after which it began to increase slowly and rose sharply in year 1999, it subsequently fell in year 2007 and rose again having a U-shape in year

\section{Trend of Government expenditure on agriculture in Nigeria between the year 1981-2016}

Government expenditure will increase demand, and thereby cause an increase in agricultural production. An increase in government expenditure on agricultural sector will yield a positive increase in agricultural production. The graph (fig 6) shows the time trend of Government expenditure on agriculture in Nigeria from year 1981-2016. The graph revealed that Government Expenditure was abysmally low between the year 1981- 1997, it rose sharply in year 1998 and fell subsequently in year 2000. The graph also shows that year 2009 has the highest Gov. Exp.

The results presented in Table 1 showed the stationary (unit root) test conducted for all the variables. The properties of each macroeconomic variable were analyzed first in order to determine the effects of macroeconomic variables on agricultural production. Augmented Dickey Fuller was used to ensure that the data is stationary, before proceeding to the co-integration form. The series of macroeconomic variable were first differenced since previous tests showed that non-stationarity was the case (except Government expenditure on agriculture which was stationary at level) and the test was re-conducted. When all the macroeconomic variables were differenced, the result of the unit root test indicated that the null hypothesis of non-stationarity was rejected and therefore, the alternative was accepted. This implied that all the macroeconomic variables in consideration were generated by similar stochastic process and they exhibit the possibility of moving together in the long-run. The table showed the critical value at 5\%, which indicates that if the absolute value of the ADF test is lower than 5\% critical ADF statistics, the null hypothesis of non-stationary is accepted.

The result of Error correction Model was presented in table 2. From the table the short-run ECM estimation for Agricultural GDP in the Nigeria was shown. Agricultural GDP (dependent variable) was tested against the independent variables; External debt (Ex. D), Crude Oil Price (COP), Credit to Agricultural Sector (CAS), Exchange rate (Ex. Rate), Government Expenditure on Agriculture (Gov. Exp), Interest Rate (IR). The result showed the Crude Oil Price, Credit to Agricultural Sector, and the Exchange Rate to be significant at 1\%. The ECM estimation shows that the COP, CAS and Ex. Rate are significant and have a Short-run relationship with Agricultural GDP. Also, COP, CAS, Ex. Rate and Ex. Debt are positively related to Ag. GDP in Nigeria, which implies that an increase in COP, CAS, Ex. Rate and Ex. Debt will yield an increase of 28994.45, 1.029879, 21957.85 and 0.0000437 respectively to the Agricultural GDP; while Gov. Exp and IR are negatively related to Ag. GDP, indicating that an increase in Gov. Exp and IR will lead to a decrease of 0.0000164 and -40434.25 to the Agricultural GDP.

The Engle-Granger test presented in the Table 3 shows the Long-run ECM estimation for Agricultural GDP in Nigeria [23]. Agricultural GDP is regressed against the independent variables which are External Debt (Ex. Debt), Crude Oil Price (COP), Credit to Agricultural Sector (CAS), Exchange Rate (Ex. Rate), Government Expenditure on Agriculture (Gov. Exp) and Interest Rate (IR). The result showed Credit to Agricultural Sector to be significant (CAS) at $1 \%$, Exchange Rate (Ex. Rate) to be significant at 10\%, and the other variables; Ex. Debt, COP, Gov. Exp, IR to be insignificant at the Long-run. Crude Oil Price (COP), Credit to Agricultural Sector (CAS), Exchange Rate (Ex. Rate), and Government Expenditure on Agriculture (Gov. Exp) are positively related to the dependent variable. This implies that an increase in these variables will likely lead to an increase of 5273.95, 0.4765259, 26633.51 and $2.06 \mathrm{e}-06$ respectively in the Agricultural GDP; while External Debt (Ex. Debt) and Interest Rate (IR) are negatively related to the dependent variable (Ag. GDP), indicating that an increase in Ex. Debt and IR will possibly lead to a decrease of 0.0002322 and -11262.57 in Agricultural GDP. The study shows that CAS and Ex. Rate were significant to agricultural GDP which shows a relationship between them. Ex. Debt, COP, Gov. Exp and IR were not significant to agricultural 
GDP which means there is no relationship between the variables in the long rPun which leads to the rejection of the alternative hypothesis and acceptance of the null hypothesis.

\section{SUMMARY}

The Nigerian economy is agro-based, and was revealed in the literature that the agricultural sector is the engine of growth and development and therefore an increase in agricultural GDP to the sector is required. The main objective of this paper was directed towards examining the effects of macroeconomic variables on agricultural development in Nigeria using annual time series data from 1980-2016. Some econometric tools were employed to explore the relationship between the variables specified in the model. The study examined the stochastic characteristics of each time series by testing their stationary using Augmented Dickey Fuller (ADF) test to ensure that serial correlation is absent, and then we adopted the co-integration/ECM test methods to determine the long-run relationship between the independent variables. The ADF test conducted on the variables showed that while government expenditure on agriculture was stationary at level, agricultural GDP, credit to agricultural sector, external debt, crude oil price, exchange rate, and interest rate were however stationary at first difference. The Engel Granger test makes less distribution assumption and does not allow the identification of the number of co-integration vectors.

The result of the error correlation model showed that in the long run, CAS (Credit to the Agricultural Sector) and Ex. Rate (Exchange Rate) exerted significant positive influence on agricultural production while Ex. Debt (External Debt), COP (Crude Oil Price), Gov. Exp (Government Expenditure on Agriculture) and IR (Interest Rate) failed to significantly explain the variation in agricultural production in Nigeria during the period under investigation. The study concludes that macroeconomic variables have no relationship with agricultural development which leads to the acceptance of null hypothesis and the rejection of the alternative hypothesis.

\section{CONCLUSION}

The study concluded that CAS and Ex. Rate were significant to Agricultural production but other variables (Ex. Debt, COP, Gov. Exp, IR) were not significant to agricultural production in which both CAS and Ex. Rate has a positive relationship to agricultural production. It is therefore concluded that Credit to the Agricultural Sector (i.e proper funding) and Exchange Rate are indispensable for sustained agricultural production in Nigeria.

\section{RECOMMENDATIONS}

Having examine the effect of macroeconomic variables on agricultural production in Nigeria, the study specifically re-commend that: Due to inconsistency in government expenditure on the agricultural sector, the federal government expenditure on agriculture should be revised upward to enhance agricultural production, domestic production of agricultural produce should be encouraged by the government to foster and increase local production.

Shortfall in agricultural production output as a result of poor financing by the government. The government should encourage the financial institution especially the commercial banks to mobilize more financial resources (credit) towards the agricultural sector to boost agricultural production, and also to set aside funds annually for agricultural financing and to compliment government effort.

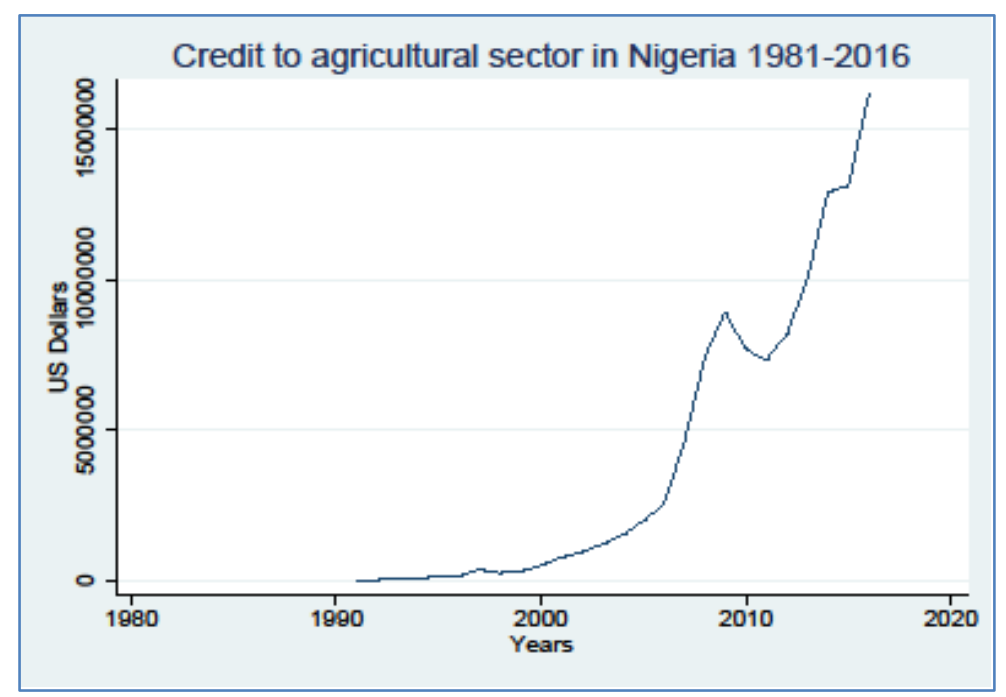

Fig-1: Credit to agricultural sector in Nigeria between the year 1981-2016 


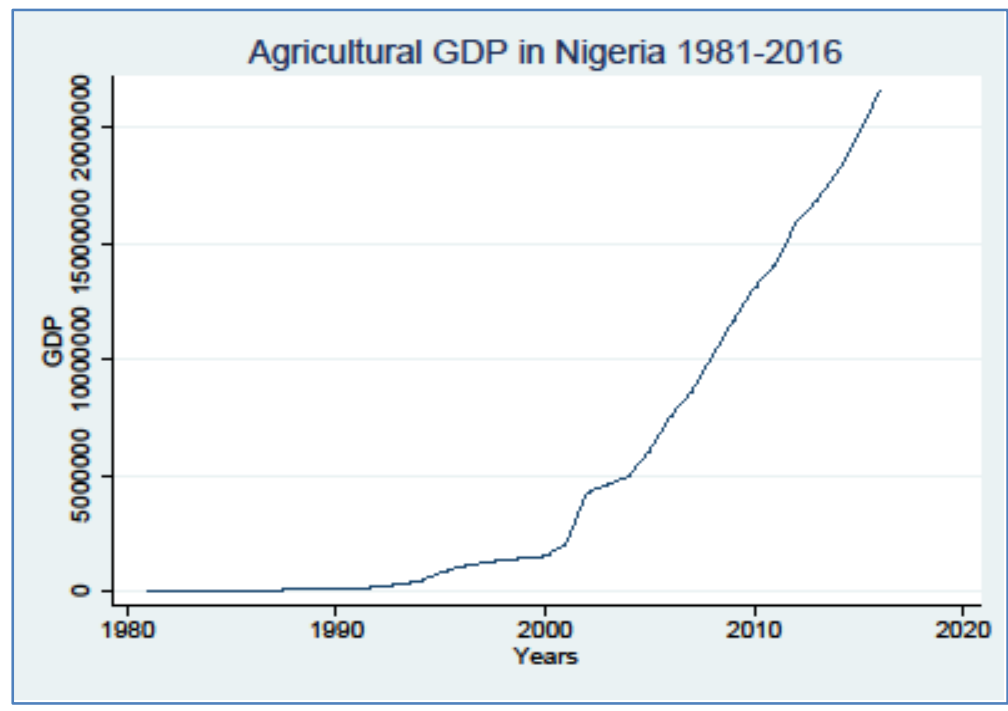

Fig-2: Agricultural GDP in Nigeria between the years 1981-2016

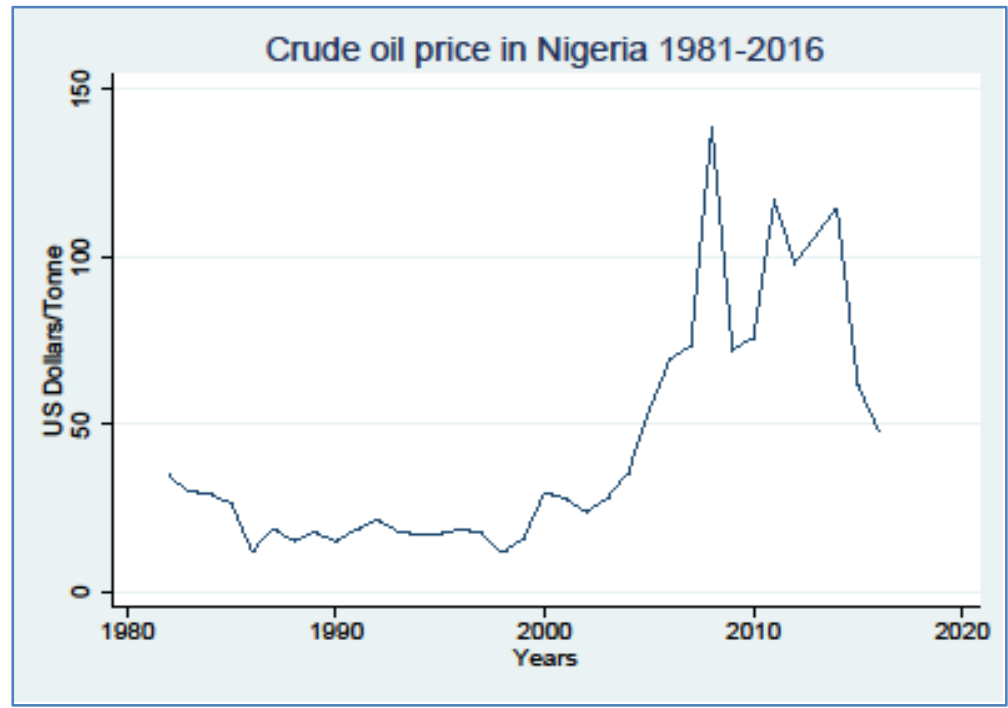

Fig-3: Crude oil price in Nigeria between the years 1981-2016

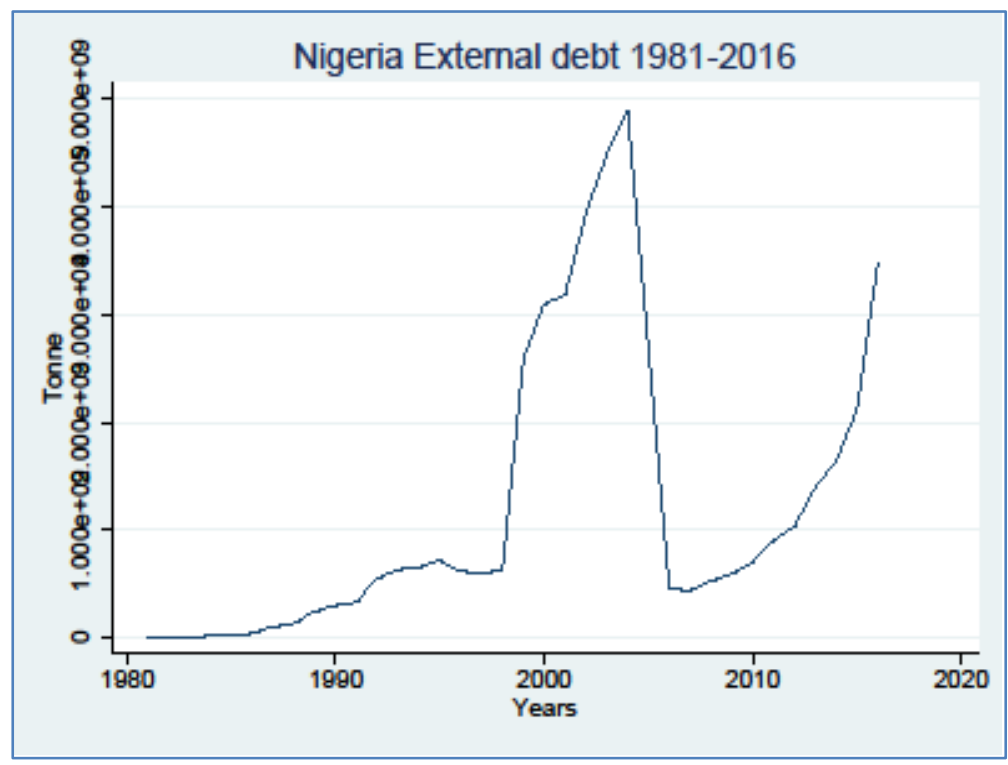

Fig-4: Exchange rate in Nigeria between 1980-2017 


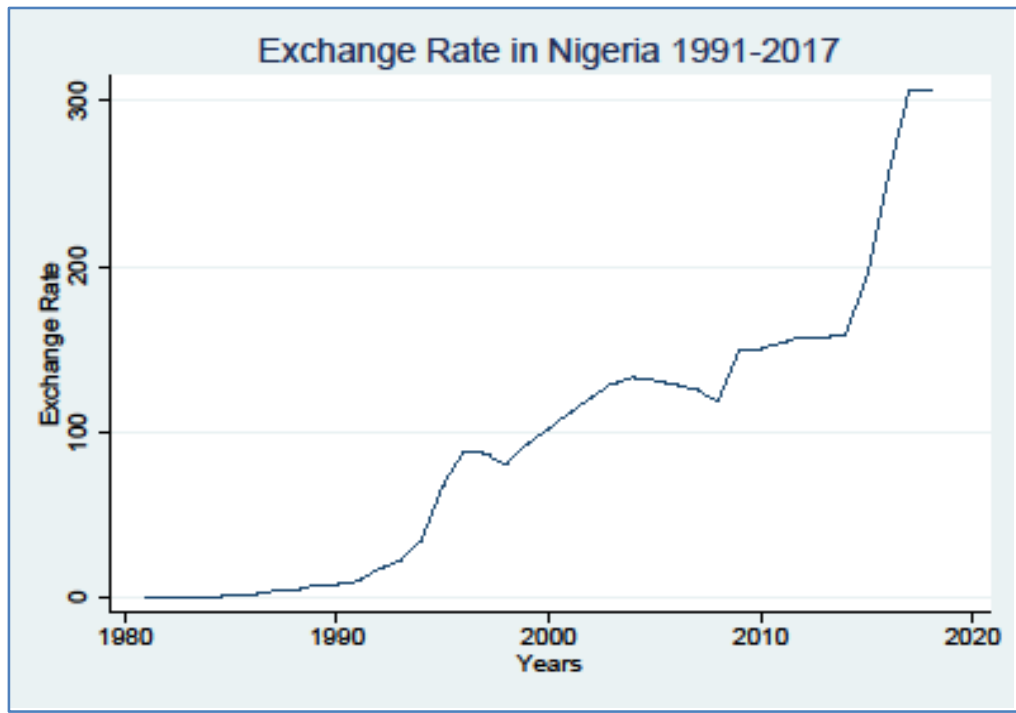

Fig.-5: Nigeria external debt between 1981-2016

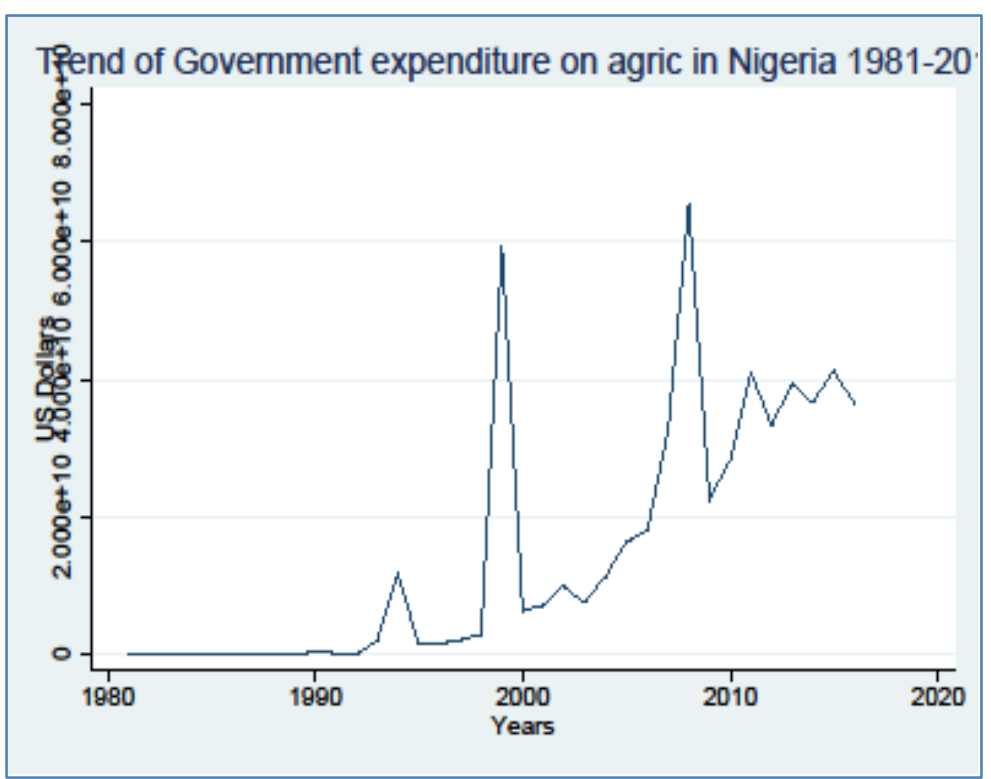

Fig-6: Trend of Government expenditure on agriculture in Nigeria between the year 1981-2016

Table-1: Augmented Dickey Fuller Unit Root Test

\begin{tabular}{|l|l|l|l|l|l|l|}
\hline \multirow{2}{*}{ Variable } & \multicolumn{3}{|c|}{ ADF (level) } & \multicolumn{3}{c|}{ ADF(1 $\mathbf{1}^{\text {st }}$ diff) } \\
\cline { 2 - 7 } & t-statistic & $\mathbf{5 \%}$ critical value & Remark & t-statistic & $\mathbf{5 \%}$ critical value & Remark \\
\hline Ag. GDP & 1.156917 & -3.544284 & Not-stationary & -5.169273 & -3.548490 & Stationary \\
\hline CAS & 3.236514 & -3.595026 & Not-stationary & -4.110395 & -3.557759 & Stationary \\
\hline Ex. Debt & -2.695380 & -3.548490 & Not-stationary & -3.301542 & -3.548490 & Not-stationary \\
\hline COP & -2.645267 & -3.544284 & Not-stationary & -7.503139 & -3.548490 & Stationary \\
\hline Ex. Rate & -2.121709 & -3.548490 & Not-stationary & -2.129175 & -3.548490 & Not-stationary \\
\hline I.R & -2.969242 & -3.557759 & Not-stationary & -2.728720 & -3.557759 & Not-stationary \\
\hline Gov. Exp & -5.557414 & -3.544284 & Stationary & & \\
\hline
\end{tabular}

Ag. GDP represents Agricultural Gross Domestic Product Ex. Debt represents External Debt

Ex. Rate represents Exchange Rate

Gov. Exp represents Government Expenditure
CAS represents Credit to Agricultural Sector COP represents Crude Oil Price I.R represents Interest Rate 
Table-2: Engel- Granger two step ECM model estimation

\begin{tabular}{|c|c|c|c|c|}
\hline \multicolumn{6}{|c|}{ The Short-run ECM model estimation } \\
\hline Ag. GDP & Coeff. & Std. Err. & $\mathrm{t}$ & $\mathrm{P}>/ \mathrm{t} /$ \\
\hline Ex. Debt & 0.0000437 & 0.0002044 & 0.21 & 0.832 \\
\hline COP & 28994.45 & 9223.212 & 3.14 & $0.004^{* * *}$ \\
\hline CAS & 1.029879 & 0.0816464 & 12.61 & $0.000^{* * *}$ \\
\hline Ex. Rate & 21957.85 & 6811.33 & 3.22 & $0.003^{* * *}$ \\
\hline I.R & -40434.25 & 43989.35 & -0.92 & 0.366 \\
\hline Gov. Exp & -0.0000164 & 0.0000162 & -1.02 & 0.318 \\
\hline Constant & -298865 & 708796.6 & -0.42 & 0.676 \\
\hline
\end{tabular}

Source: Authors Computation, 2019

*represents significance at $10 \%, * *$ represents significance at $5 \%$ and $* * *$ represents significance at $1 \%$ level

Table-3: The Long-run ECM model estimation

\begin{tabular}{|c|c|l|c|c|}
\hline Ag. GDP & Coeff. & Std. Err. & T & P>/t/ \\
\hline Ex. Debt & -0.0002322 & 0.0001767 & -1.31 & 0.200 \\
\hline COP & 5273.95 & 7116.577 & 0.74 & 0.465 \\
\hline CAS & 0.4765259 & 0.1386464 & 3.44 & $0.002^{* * *}$ \\
\hline Ex. Rate & 26633.51 & 13729.75 & 1.94 & $0.063^{*}$ \\
\hline Gov. Exp & $2.06 \mathrm{e}-06$ & $7.80 \mathrm{e}-06$ & 0.26 & 0.794 \\
\hline IR & -11262.57 & 30086.59 & -0.37 & 0.711 \\
\hline
\end{tabular}

Source: Authors Computation, 2019

*represents significance at $10 \% * *$ represents significance at $5 \%$ and *** represents significance at $1 \%$ level

\section{REFRENCES}

1. Matton, P., Adelakoun, V., Couture, Y., \& Dufour, J. J. (1981). Growth and replacement of the bovine ovarian follicles during the estrous cycle. Journal of Animal Science, 52(4), 813-820.

2. Akinniran, T. N. (2011). Supply Chain Management and Performance of Cocoa Industry in Nigeria. Unpublished $\mathrm{PhD}$ Thesis in the Department of Agricultural Economics, Ladoke Akintola University of Technology, Ogbomoso.

3. Ahmed, Y.O. (1993). Bank of the North Pamphlets on Agricultural Financing Various circulars and Policy Guidelines on Agricultural Financing in Bank of the North Limited. A Seminar paper delivered at Bank of the North Human Resources and Development Centre.

4. Okolo, (2004). Impact of Agricultural Sector on Economic Growth of Nigeria; https://educacinfo.com.

5. Emeka, O. M. (2007). Improving the agricultural sector toward economic development and poverty reduction in Nigeria. CBN Billion, 4:23-56.

6. Fabiyi, Y. L. (1979). Land tenure reform in Nigeria: Implication of the Land Use Decree for Agricultural Development. Ife Journal of Agriculture, 1(2): 235-127.

7. Ogen, O. (2003). "Patterns of Economic Growth and Development in Nigeria since 1960" in S. O. Arifalo and Gboyega, A (eds.). (2003). Essays in Nigerian] Contemporary History. Lagos: First Academic Publishers.

8. Eyo, E. O. (2008). Macroeconomic environment and agricultural sector growth in Nigeria. World Journal of Agricultural Sciences, 4(6), 781-786.

9. Omotor, D. G., Orubo, C. O., \& Inoni, E. (2009). Policy Reforms and Agricultural Exports in Nigeria: An Empirical Analysis. The Singapore Economic Review, 54(04), 589-603.

10. Alex, N. (2018). Environmental factors affecting agricultural production in Nigeria. http//www.legit.ng.net.

11. Zarnowitz, V. (1992). Major Macroeconomic variables and Leading indexes. University of Chicago Press, 357 - 382

12. Rightsman, D. (1986). An Introduction to Monetary Theory and Policy, New York, the Free Press.

13. Lachaal, L. (1994). "Subsidies, Endogenous Technical Efficiency and the Measurement of Production Growth" Journal of Agriculture and Applied Economics, 26(1): 299-310.

14. Fan, H., Wang, D., Bai, W., \& Liu, J. (2012). Starch-sodium stearate complex modified PCC filler and its application in papermaking. BioResources, 7(3), 3317-3326.

15. Yaqub, J. O. (2012). "Exchange Rate Changes and Output Performance in Nigeria: A Sectoral Analysis", Pakistan Journal of Social Science, 7(5), 380-387.

16. Adetoun, O. (2010). "Effect of Monetary policy on agricultural output in Nigeria" http://www.academia.edu/1347756/The_Effect_of_monetary_policy_on_agricultural_output_in_Nigeria.

17. Egbuwalo, M.O. (2003). "Analysis of Agricultural Production and Financing under a Deregulated Economy: Case Study of Small -Scale Farmers in Ekiti and Ondo State, Nigeria", an unpublished PhD Thesis in The Department of Agricultural Economics And Extension, The Federal University of Technology, Akure

18. Enoma, A. (2011). "Agricultural Credit and Economic Growth in Nigeria: An Empirical Analysis", Business and Economics Journal, BEJ-14 pp1-7http://astonjournals.com/manuscripts/Vol2010/BEJ14_Vol2011.pdf . 
19. Brownson, S., Vincent, I. M., Emmanuel, G., \& Etim, D. (2012). Agricultural productivity and macro-economic variable fluctuation in Nigeria. International Journal of Economics and Finance, 4(8), 114-125.

20. Memon, M. H., Baig, W. S., \& Ali, M. (2008). Causal relationship between exports and agricultural GDP in Pakistan.

21. Katircioglu, S. T. (2006). Causality between agriculture and economic growth in a small nation under political isolation. International Journal of Social Economics.

22. Central Bank of Nigeria. (2008). Annual report and financial statements. (CBN), Abuja. (2009). Macro econometric model of the Nigerian economy.

23. Engle, R. F., \& Granger, C. W. (1987). Co-integration and error correction: representation, estimation, and testing. Econometrica: journal of the Econometric Society, 251-276.

24. Statistics South Africa. (2010). Quarterly labour force survey. Statistics South Africa.

25. Johansen, S. (1991). Estimation and hypothesis testing of cointegration vectors in Gaussian vector autoregressive models. Econometrica: journal of the Econometric Society, 1551-1580.

26. Wikipedia. (2016). Nigeria. Available online at www.en.wikipedia.org/Nigeria Retrieve on August 6, 2019. 